\title{
PENGARUH CITRA MEREK DAN PERSEPSI KUALITAS PELAYANAN PELAYANAN TERHADAP KEPUTUSAN PEMBELIAN PADA ONLINE TRAVEL AGENT AIRASIA GO
}

\author{
Ni Kadek Ayu Marini Sarasdiyanthi \\ I GPB. Sasrawan Mananda \\ I Wayan Suardana \\ Email: ayum768@gmail.com \\ PS.S1 Industri Perjalanan Wisata \\ Fakultas Pariwisata UNUD
}

\begin{abstract}
ABSTRAK
Airasia Go sedang mengupayakan untuk membentuk citra merek dan persepsi kualitas pelayanan terhadap wisatawan agar dapat mengetahui sejauh mana pengaruh citra merek dan persepsi kualitas pelayanan terhadap keputusan pembelian pada online travel agent Airasia Go tersebut. Tujuannya adalah untuk mengetahui respon wisatawan terhadap citra merek dan persepsi kualitas pelayanan terhadap keputusan pembelian pada produk jasa Airasia Go, mengetahui besarnya pengaruh citra merek dan persepsi kualitas pelayanan secara parsial dan simultan terhadap keputusan pembelian.

Metode yang digunakan adalah metode kuantitatif dan kualitatif. Pengambilan sampel menggunakan metode non probability sampling jenis accidental sampling dengan jumlah 110 responden. Untuk analisis data menggunakan teknik analisis berganda, korelasi berganda, analisis determinasi, uji t dan uji F.

Dari uji t diperoleh hasil bahwa citra merek dan persepsi kualitas pelayanan berpengaruh positif terhadap keputusan pembelian dengan nilai $t$ hitung 5,685 untuk variabel persepsi kualitas pelayanan dan 6,261 untuk variabel citra merek. Dari uji $\mathrm{F}$ diperoleh hasil bahwa citra merek dan persepsi kualitas pelayanan berpengaruh positif dan signifikan terhadap keputusan pembelian dengan nilai $\mathrm{F}_{\text {hitung }} 119,337$.
\end{abstract}

Kata Kunci : Citra Merek, Persepsi Kualitas Pelayanan, Keputusan Pembelian.

\section{PENDAHULUAN}

Perkembangan zaman yang pesat saat ini membuat semua keterbatasan waktu, jarak dan biaya dapat diatasi dengan mudah dengan adanya internet. E-marketer memproyeksikan bahwa pada tahun 2017 pengguna internet di Indonesia akan menembus angka 112,6 juta pengguna dan akan naik pada tahun 2018 sebesar 123 juta pengguna.

Peningkatan pada jumlah pengguna internet, telah menarik minat berbagai jenis usaha bisnis untuk memasarkan produknya atau jasa secara online. Saat ini jenis jasa yang banyak ditawarkan situs online adalah pemesanan tiket pesawat, voucher hotel dan lain sebagainya.
Situs online penjualan tiket pesawat dan voucher hotel memudahkan wisatawan untuk dapat mengakses informasi dimana saja, kapan saja tanpa mengharuskan konsumen untuk datang langsung ke tempat penjualan tiket tersebut. Airasia Go merupakan salah satu situs yang menyediakan jasa penjualan tiket pesawat dan voucher hotel.

Airasia Go dikelola oleh Airasia Expedia bekerjasama dengan sebuah perusahaan gabungan antara perusahaan travel online Expedia, Inc dan maskapai Airasia.

Persaingan yang cukup signifikan antara travel online satu dan lainnya, membuat perusahaan harus menerapkan suatu citra 
merek yang positif kepada para konsumen agar dapat membentuk kepuasan dalam diri konsumen yang akan menghasilkan persepsi kualitas atau pandangan konsumen terhadap suatu merek yang pada akhirnya akan menentukan terjadinya keputusan pembelian (Levy,S.J 1973).

Citra merek adalah apa yang dipersepsikan oleh konsumen mengenai sebuah merek (Susanto 2011). Citra merek menurut Keller (2003) diukur dengan variabel yaitu : keunggulan asosiasi merek, kekuatan asosiasi merek, keunikan asosiasi merek. Dalam penelitian Ikanita Novirina (2012) menyatakan bahwa citra merek dengan sangat kuat mempengaruhi keputusan pembelian.

Persepsi kualitas pelayanan menurut Durianto (2001) didefinisikan sebagai persepsi pelanggan terhadap keseluruhan kualitas atau suatu produk atau jasa yang berkaitan dengan apa yang diharapkan pelanggan. Zeitaml dan Bittner dalam (Umar 2003) ada lima dimensi menentukan kualitas jasa yaitu : reliability (dapat dipercaya, responsiveness (kemampuan), assurance (jaminan), emphaty (perhatian), tangibles (penampilan fisik). Penelitian Ahmad, Noor dan Wei (2014) menyatakan bahwa persepsi kualitas pelayanan berpengaruh terhadap keputusan pembelian

Keputusan pembelian adalah suatu keputusan yang melibatkan pilihan diantara dua atau lebih alternatif tindakan atau perilaku, Setiadi (2003).

Menurut Kotler dan Amstrong (2006) proses keputusan pembelian terdiri atas urutan sebagai berikut: pengenalan masalah, pencarian informasi, evaluasi alternatif, keputusan pembelian dan perilaku pasca pembelian. Citra merek dan Persepsi kualitas pelayanan adalah variabel - variabel yang mempengaruhi keputusan pembelian. Berdasarkan latar belakang diatas ingin diketahui pengaruh citra merek dan persepsi kualitas pelayanan terhadap keputusan pembelian pada online travel agent Airasia Go.

\section{METODE PENELITIAN}

Terdapat 3 variabel yang dibahas yaitu Citra merek $\left(\mathrm{X}_{1}\right)$, Persepsi kualitas pelayanan $\left(\mathrm{X}_{2}\right)$, dan Keputusan Pembelian sebagai variabel terikat. Pengumpulan data menggunakan teknik observasi, wawancara, studi pustaka, kuisioner, dan dokumentasi. Pengambilan sampel menggunakan metode non probability sampling jenis accidental sampling menggunakan 110 responden. Responden yang digunakan adalah wisatawan yang pernah mengakses dan menggunakan jasa Airasia Go.

Teknik analisis data yang digunakan yaitu analisis data kualitatif dan kuantitatif. Untuk analisis data kualitatif menggunakan skala likert dan untuk analisis data kuantitatif menggunakan uji validitas, uji realibilitas, uji asumsi klasik (uji normalitas, uji multikolinearitas, uji heteroskedastisitas). Untuk melihat pengaruh variabel $\mathrm{X}$ terhadap $\mathrm{Y}$ menggunakan analisis regresi linier berganda, analisis korelasi, analisis determinasi, dan pengujian hipotesis menggunakan uji t, uji F.

\section{HASIL DAN PEMBAHASAN Uji Instrumen}

Uji validitas dan uji realibilitas dihitung menggunakan SPSS versi 16,0 hasil uji validitas diketahui bahwa nilai korelasi instrumen pada setiap variabel lebih besar dari 0,270, maka menunjukan bahwa instrumen setiap variabel ini dinyatakan valid. Pada uji realibilitas diketahui bahwa seluruh instrumen variabel memiliki nilai alpha cronbach's lebih besar dari 0,60 sehingga instrumen setiap variabel dinyatakan reliabel atau memiliki ketepatan data yang baik.

\section{Analisis Data Deskriptif}

Penilaian responden mengenai variabel citra merek mendapatkan nilai total rata - rata 3,32, maka ini menerangkan bahwa responden Airasia Go memberikan respon cukup setuju untuk setiap pernyataan mengenai variabel citra merek.

Penilaian responden tentang variabel persepsi kualitas pelayanan mendapat nilai rata - rata 3,34, ini menunjukkan bahwa responden memberikan respon cukup setuju pada indikator pernyataan persepsi kualitas pelayanan dan pada variabel keputusan pembelian nilai rata - ratanya sebesar 3,24 ini juga menunjukkan bahwa responden memberikan respon cukup setuju pada pernyataan terhadap keputusan pembelian.

\section{Uji Asumsi Klasik}

Berdasarkan hasil uji multikolinearitas dapat diketahui bahwa nilai tolerance untuk masing- masing variabel bebas $>10 \%$ dan nilai variance inflation factor (VIF) $<10$, maka menunjukan bahwa tidak adanya hubungan 
antara variabel $\mathrm{X}_{1}$ citra merek dan $\mathrm{X}_{2}$ persepsi kualitas pelayanan sehingga dapat dilanjutkan pada pengolahan regresi berganda.

Uji heterokedastisitas menggunakan uji Glejser menunjukkan bahwa tidak terdapat pengaruh pada masing - masing variabel bebas terhadap absolute residual yang diketahui nilai signifikansi $>0,05$, hal ini dapat diartikan bahwa tidak adanya hubungan antara kedua variabel bebas.

Uji normalitas dengan statistis Kolmogrov Smirnov menjelaskan bahwa nilai asymp. Sig (2-tailed) sebesar 0,331 berarti data yang digunakan dalam penelitian ini terdistribusi normal.

\section{Analisis Regresi Linear Berganda}

Untuk mengetahui ada tidaknya pengaruh citra merek $\left(\mathrm{X}_{1}\right)$ dan persepsi kualitas pelayanan $\left(\mathrm{X}_{2}\right)$ terhadap keputusan pembelian digunakan perhitungan regresi dengan SPSS. Adapun hasil analisis regresi linear berganda yaitu :

$\mathrm{Y}=0,780+0,509 \mathrm{X} 1+0,256 \mathrm{X} 2$

Keterangan :

$\mathrm{Y}=$ Keputusan Pembelian

$\mathrm{a}=$ Konstanta

$\mathrm{X} 1=$ Citra Merek

X2 = Persepsi kualitas pelayanan

Hal ini menjelaskan bahwa variabel bebas berpengaruh positif terhadap variabel terikat, artinya peningkatan yang terjadi pada variabel citra merek $\left(\mathrm{X}_{1}\right)$ dan persepsi kualitas pelayanan $\left(\mathrm{X}_{2}\right)$ akan berdampak pada meningkatnya keputusan pembelian (Y).

\section{Analisis Korelasi}

Korelasi Parsial digunakan untuk menguji signifikansi hubungan dari semua variabel bebas secara keseluruhan dengan variabel terikat. Hasil analisis korelasi menunjukan bahwa nilai $\mathrm{R}$ sebesar 0,831, maka hubungan yang terdapat pada citra merek dan persepsi kualitas pelayanan terhadap keputusan pembelian memiliki korelasi atau hubungan yang sangat kuat.

\section{Analisis Determinasi}

Analisis determinasi dilakukan untuk mengetahui presentase konstribusi pengaruh variabel bebas yang meliputi citra merek $\left(\mathrm{X}_{1}\right)$ persepsi kualitas pelayanan $\left(\mathrm{X}_{2}\right)$ terhadap variabel terikat keputusan pembelian (Y). Adapun nilai $\mathrm{R}$ square yaitu 0,690 , maka presentase pengaruh citra merek, persepsi kualitas pelayanan, terhadap keputusan pembelian koefisien determinasinya sebesar $69 \%$. Sedangkan sisanya sebesar $31 \%$ dipengaruhi variabel - variabel lain diluar citra merek dan persepsi kualitas pelayanan.

\section{Uji Hipotesis}

Uji t digunakan untuk mengetahui hubungan variabel bebas berpengaruh terhadap variabel terikat secara parsial. Hasil uji $t_{\text {hitung }}$ variabel citra merek, persepsi kualitas pelayanan $(6,261$ dan 5,685$)$ lebih besar dari nilai $t$ tabel $(1,659)$ dan nilai signifikansi yang lebih kecil dari 0,05.

Uji F untuk mengetahui signifikansi pengaruh variabel citra merek, persepsi kualitas pelayanan secara bersama - sama terhadap variabel keputusan pembelian. Hasil uji $\mathrm{F}$ menunjukan bahwa $\mathrm{F}_{\text {hitung }}$ 119,337 lebih besar dari nilai $F_{\text {tabel }} 3,08$, dengan nilai signifikansi $0,000<0,05$.

\section{Pengaruh Citra Merek terhadap Keputusan Pembelian Online Travel Agent Airasia Go.}

Diperoleh hasil bahwa citra merek $\left(\mathrm{X}_{1}\right)$ berpengaruh positif dan signifikan terhadap keputusan pembelian (Y) dengan nilai t hitung lebih besar dari t tabel sebesar 6,261 > 1,659. Hasil ini mengarah kearah yang positif ini berarti semakin tinggi atau positif citra merekmaka akan semakin meningkatkan keputusan pembelian.

Citra yang positif menjadi faktor penentu bagi merek yang digunakan oleh produk tersebut. Merek yang baik merupakan salah satu kunci bagi perusahaan untuk dapat mempengaruhi pandangan konsumen, sehingga akan memberikan kesan yang positif terhadap produk maupun perusahaan dan akan menimbulkan adanya keputusan pembelian.

\section{Pengaruh Persepsi Kualitas Pelayanan terhadap Keputusan Pembelian Online Travel Agent Airasia Go}

Diketahui pada hasil uji t menunjukan bahwa nilai $t$ hitung lebih besar dari $t$ tabel sebesar 5,685 > 1,659 dan hipotesis diterima kearah yang positif, semakin meningkatnya persepsi kualitas pelayanan maka semakin meningkat pula keputusan pembelian wisatawan pada online travel agent Airasia Go.

Persepsi kualitas pelayanan menggambarkan perasaan wisatawan terhadap keseluruhan kualitas produk dan jasa layanan 
yang ditawarkan dengan tujuan dapat memenuhi harapan wisatawan.

\section{Pengaruh Citra Merek Persepsi Kualitas Pelayanan terhadap Keputusan Pembelian Pada Online Travel Agent Airasia Go}

Citra merek, persepsi kualitas pelayanan mempengaruhi keputusan pembelian secara bersama - sama dengan nilai $\mathrm{F}_{\text {hitung }}$ lebih besar dari $F_{\text {tabel }}$ sebesar 119,337> 3,08 dengan taraf signifikansi, $0,000<0,05$. Hal ini berarti citra merek dan persepsi kualitas pelayanan secara serempak atau bersama - sama berpengaruh signifikan terhadap keputusan pembelian.

Persepsi kualitas pelayanan memiliki peranan penting dalam suatu merek. Merek yang positif menjadi alasan untuk membangun citra perusahaan yang positif. Citra merek yang baik merupakan salah satu yang mela tarbelakangi terjadinya keputusan pembelian. Keputusan pembelian dipengaruhi oleh persepsi kualitas pelayanan suatu merek yang ada di pikiran wisatawan, sehingga sering dijadikan alasan pengambilan keputusan pembelian pada produk atau jasa yang ditawarkan.

\section{SIMPULAN DAN SARAN Simpulan}

Dari pembahasan dapat disimpulkan yaitu variabel citra merek $\left(\mathrm{X}_{1}\right)$ mempengaruhi keputusan pembelian secara positif dan signifikan dilihat dari hasil $\mathrm{t}$ hitung yang lebih besar dari t tabel 6,261>1,659 dan variabel persepsi kualitas pelayanan juga menunjukkan nilai $\mathrm{t}$ hitung lebih besar dari $\mathrm{t}$ tabel 5,685 > 1,659 yang menjelaskan bahwa variabel persepsi kualitas pelayanan $\left(\mathrm{X}_{2}\right)$ berpengaruh signifikan dan positif terhadap keptusan pembelian.

Dan uji secara simultan dengan uji $\mathrm{F}$ diketahui bahwa citra merek, persepsi kualitas pelayanan, berpengaruh positif dan signifikan secara bersama - sama mempengaruhi keputusan pembelian dengan nilai $\mathrm{F}_{\text {hitung }}$ lebih besar dari nilai $\mathrm{F}_{\text {tabel }}$ sebesar 119,337>3,08.

\section{Saran}

Perusahaan Airasia Go dapat menjaga, mempertahankan, dan meningkatkan citra merek dan persepsi kualitas pelayanan perusahaan dengan peningkatan kualitas yang nyata sehingga dapat memperkuat persepsi pelanggan yang telah melakukan pembelian pada online travel agent Airasia Go. Selain itu penelitian ini dapat dujadikan masukan untuk Airasia Go.

Untuk penelitian selanjutnya diharapkan menambah variabel bebas dan memfokuskan penelitian agar dapat memperjelas lagi tentang keputusan pembelian.

\section{DAFTAR PUSTAKA}

Ahmad, Azhar, Salehuddin Mohd Noor,Che Aniza Che Wel. 2014. Factors Influencing Consumers Purchase Decision of Private Label brand Products. International Journal of Economic Practices and Theories. Vol. , No. 2, 2014

Durianto, Darmadi. 2001. Strategi Menaklukan Pasar Melalui Riset Ekuitas dan Perilaku Merek. Jakarta: Gramedia Pustaka Utama

Ikanita, Novirina. 2012. Analisis Pengaruh Citra merek, Kualitas Produk, dan Harga Terhadap Keputusan Pembelian produk Oriflame. Semarang: Skripsi Universitas Udayana.

Keller, KL. 2003. Strategic Brand management, building easurement and Managing Barnd Equity. Upper Sadle River, NJ Pearson Education International.

Kotler \& Amstrong, 2006, Prinsip-Prinsip Pemasaran. Jakarta: Erlangga

Levy, S.J. and Glick, I.O. (1973), “ Imagery and Symbolism”, Marketing Manager's Handbook, Steward H. Britt, Editor (Chicago, II. : Dartnell).

Setiadi,Nugroho. 2003. Perilaku Konsumen.Jakarta : Kencana

Susanto, A.B, Himawan Wijanarko. 2004. Power Branding: Membangun Merek Unggul dan Organisasi Pendukungnya.Jakarta: Quantum Bisnis dan Manajmenen

Umar, Husein. 2003. Metode Riset bisnis. Jakarta: PT. Gramedia Pustaka Utama.

Wahab, Saleh. 1997. Pemasaran Priwisata. Jakarta: PT. Pradnya Paramita. 